\title{
Agitair 浮選機の槽底におけるかくはんに関する研究*
}

(第 2 報)

$\begin{array}{llll}\text { 正会員 守 屋 } & \text { 格** } \\ \text { 正会員 松 村 博 昭 }\end{array}$

Studies on Agitation at the Bottom of the Agitair Flotator

(2nd Report)

Itaru MORIYA, and Hyroaki MATSUMURA

In this report, the motion of pulp and bubbles in the Agitair flotation cell and the correlation between their motion and intensity of agitation at the bottom of the cell were investigated by using a small batch cell provided with a stabilizer. The results obtained are as follows:-

1. It was ascertained that the impeller had an specific height $H_{0}$ * to keep the flow of water and bubbles in good condition.

2. It was demonstrated that the impeller had an optimum height $H_{e}$ to keep the flow of pulp in good condition, and when specific gravity, size and quanuity of particles were given, $H_{e}$ was affected chiefly by the value $H_{0} *$. In our experiment, $H_{e}$ had existed in the range of $38 \sim 66 \%$ of the height of stabilizer from bottom of the cell.

3. In order to make agitation effective, it is necessary to set the impeller below its optimum height $H_{e}$.

4. When the impeller is set below its optimum height $H_{e}$, intensity of agitation at the bottom of the cell increases in proportion to the number of slits and the circumferential velocity of the impeller. It, however, dereases with increase of air quantity introduced in the cell and the height of the impeller from the bottom, being independent of the height of stabilizer from the bottom of the cell.

\section{1. 緒言}

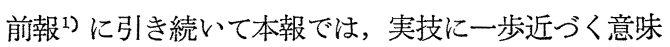
で，ビやま板を挿入した水槽と違つたスリット数をもつ インペラとを組合せたかくはん装置を使用し，インペラ とじやま板のそれぞれの各設置高度についてインペラの 外周速度と供給空気量を変えて実験を行なつた。それに よつて種々の運転条件下に扝けるじやま板付き槽内の鉱 粒と気泡の動態を解明するとともに, 槽底に生ずるかく はん強さを比䩙し，この両者に及ぼすじやま板の影響に ついて考察を加えると同時にこの両者の相関関係を明確 にすることを試みた。

\section{2. 実験の装置と方法}

実験装置は，供試槽を除いては前回の装置をそのまま 使用した。供試槽は第 1 図に示すように, 前回の槽の内 部にじやま板を插入したもので， じやま板は鉱粒投入量

* 昭和 37 年 12 月 20 日受理

*** 秋田大学鉣山学部助教授 鉣山機械学教室

**** 東北大学高速力学研究所助手
を多くした場合に限り真鍮板製のものを用い，その他の 場合にはガラス板製のものを用いた。計器類及び各要項

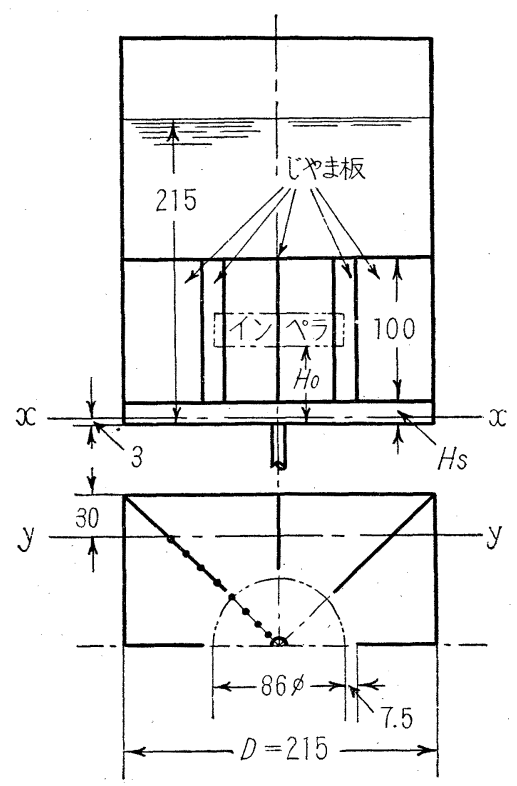

第 1 図 供 試 槽 
測定の方法，䉇囲等は前回におけるとほぼ同様である。

じやま板付き槽内の流動は, じやま板なし槽内の流動 に較べて一段と複雑になるので, その流相の查定に当つ ては，簡易に測定ができてしかも比較的適確な結果を与 える系流し試験法によつた。この試験法注浮選機方向で は林により Fahrenwald 型機内の流相確定の際にピト 一管と併用されて好結果をむたらしている2)ので，本実 験においてもこの試験法（本実験では80番綿采使用）を 利用した。

\section{3. 実験の結果と考察}

\section{3・1 じやま板付き楂内における流れの動態}

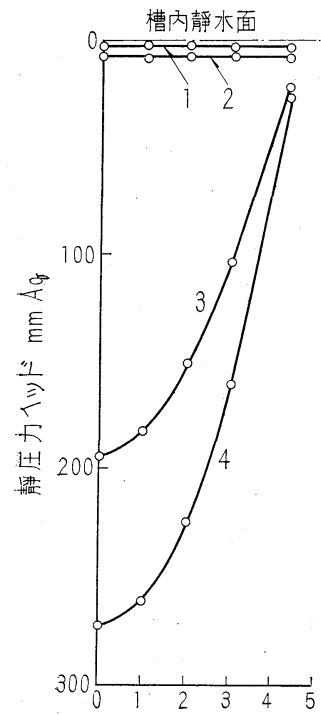

槽中心からの距離 $\mathrm{cm}$ (a) $Q=0$
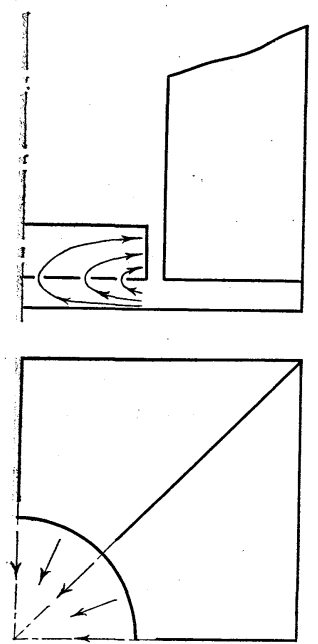

第3図 インペラ直下の流 動(コアーが存在しない時)

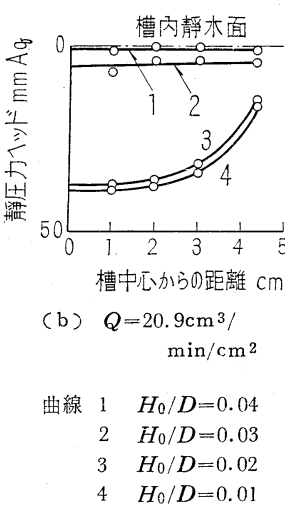

第 2 図

インペラ直下の槽 底面上に㧍ける静 圧力ヘッド分布 $\left(H_{s} / D=0.05, z=24\right.$ $u=4 \mathrm{~m} / \mathrm{sec}$ )

$3 \cdot 1 \cdot 1$ インペラ直下の 槽底における静圧差：イン ペラ直下の槽底面上におけ る静圧カヘッドを測定して みると，第 2 図に示される ような結果を得る。この測 定值には多少の動圧の影響 を含むと考えられるが，そ の影響は僅少と推察される ので，これらの曲線は静圧 カヘッド分布の姿をほぼ示 すものとみなすことができ る。第 2 図に示される曲線 は, $H_{0} / H_{s}$ が小さい時に は, じやま板なし棤におい てみられたと同様な放物線
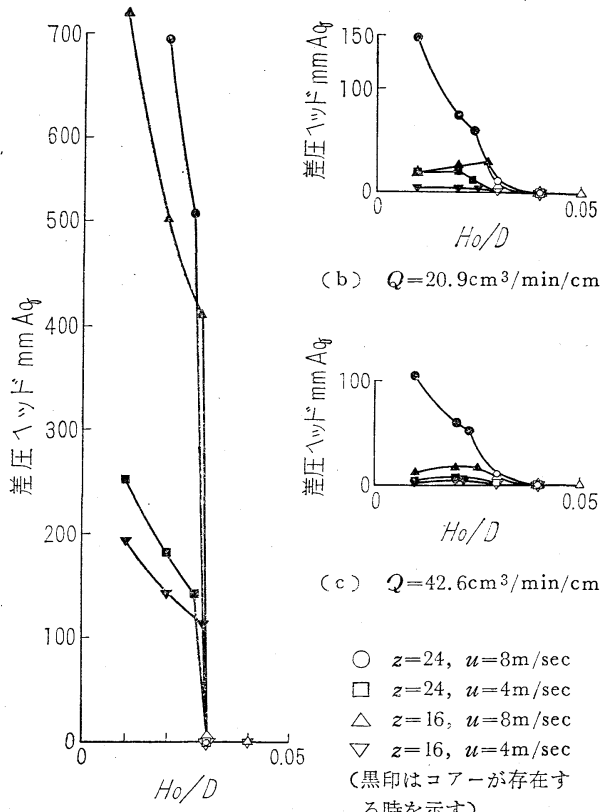

(b) $Q=20.9 \mathrm{~cm}^{3} / \mathrm{min} / \mathrm{cm}^{2}$

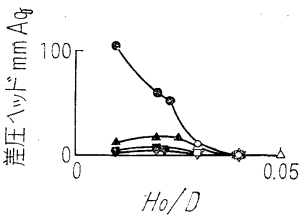

(c) $Q=42.6 \mathrm{~cm}^{3} / \mathrm{min} / \mathrm{cm}^{2}$

$z=24, u=8 \mathrm{~m} / \mathrm{sec}$ $\square \quad z=24, u=4 \mathrm{~m} / \mathrm{sec}$ $\triangle z=16, u=8 \mathrm{~m} / \mathrm{sec}$ $\nabla \quad z=16, u=4 \mathrm{~m} / \mathrm{sec}$ (黑印はコアーが存在す ( a ) $Q=0$

第4図インペラ直下の槽底面上の円形区域に扣け る中心と外周䦭の差圧へッド $\left(H_{s} / D=0.05\right)$

に近い形状を呈し， $H_{0} / H_{s}$ が大きい時には， $H_{1} / D$ に 対する圧力勾配が㠴るやかな直線に近い形状を呈してい る。したがつて $H_{0} / H_{s}$ が比較的小さい時は，槽底にお ける流れはじやま板の影響を受けることが少なく，イン ペラの直下にはいわゆるコアが存在するが， $H_{0} / H_{s}$ が 比較的大きい時は，槽底における流れはじやま板の影響 を受けることが多く、インペラの直下にはもはやコアが 存在しないでコアと性質が異なる流動が生じていること がわかる。このようなコアと異なる別種の流動は系流し の結果によれば，ほぼ第 3 図に示されるような輻流であ

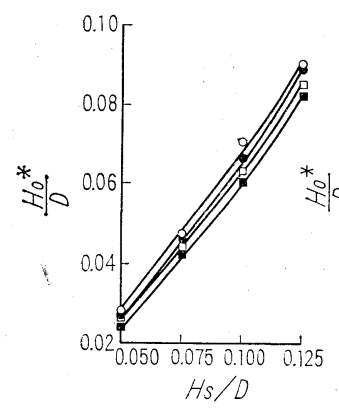

(a) $u=\tilde{\mathrm{m}} / \mathrm{sec}$

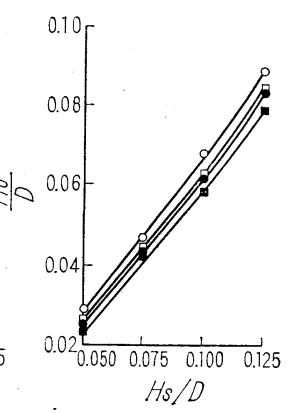

(b) $u=4 \mathrm{~m} / \mathrm{sec}$
○ $z=16 Q=0$
- $z=16 Q=20.9 \mathrm{~cm}^{3} / \mathrm{min} / \mathrm{cm}^{2}$
$\square \quad z=24 Q=0$
$z=24 Q=20.9 \mathrm{~cm}^{3} / \mathrm{min} / \mathrm{cm}$

第 5 図 $H_{0}^{*} / D$ と $H_{s} / D$ との関係 
ると推察されるがロ，第 2 図に示される静圧力へッド分 布曲線は，このような輻流において現われると考えられ る圧力公配線にほぼ一致する。

第 4 図は，第 2 図に示されるような静圧力ヘッド分布 曲線を基として求められる。インペラ直下の槽底向上の 円形区域における中心と外周間の静圧力の差圧へッドの 值及びコアの存在する範囲を併わせて表示した図であ る。この図に示されるコアの存在範囲内における差圧へ ッドは, じやま板なし槽の底面上に㧍汀るコアの中心と 外周間の差圧へッドに較べれば，大きさの点で数十\%程 度の増減がみられるにもかかわらず，両差圧へッドの $z, u, Q, H_{0} / D$ 亿対して変わる傾向はほぼ一致している。 これによつて, 槽底面上においてコアの中心と外周間に 生ずる差圧へッドは, じやま板の有無によつてその大き さはかなり大きく変動するが，その $z, u, Q, H_{0} / D$ に対 して変わる傾向はほとんど変わらないものといえる。

第 5 図は，第 4 図に示したようなコアの存在範囲内の $H_{0} / D$ の上限值 $H_{0} * / D$ をじやま板の各設置高度につい て求めた結果を示す。この図にみられるように, $H_{0} * / D の$ 值は, $H_{s} / D$ とともに増し, $z, Q$ が増せば減少し， $u$ が増せば, $Q=0$ の場合には $H_{s} / D$ の值に応じて増加, 減少，不変のいぶれかとなり，Q>0 の場合にはす心゙て 増加している。

$3 \cdot 1 \cdot 2$ じやま板直下の領域内における流動図：ビや

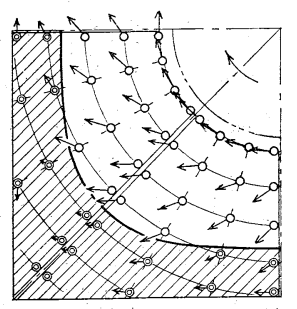

(a)

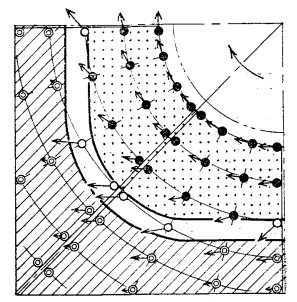

(b)

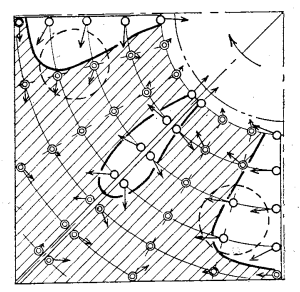

(C)

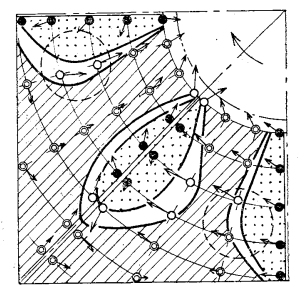

(d)
○上暴流
Q⿻上丨丶异流昨在区域
○水平流
- 下降流
水平流日存在区域
下降流时存在区域

(a), (b) \& $H_{0} / D=0.02$, (c), (d) \& $H_{0}{ }^{\prime} D=0.05$ の時 (a), (c) \& $H_{m} \fallingdotseq 0.1 H_{s}$, ( b ), (d) \& $H_{m} \fallingdotseq 0.9$ の場合

第 6 図じやま板直下の領域内に打ける流動 $\left(H_{s} / D=0.05, z=24, u=6 \mathrm{~m} / \mathrm{sec}\right.$ )

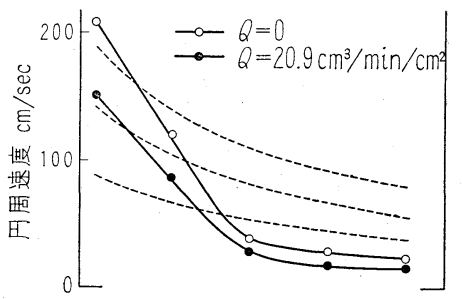

第 7 図

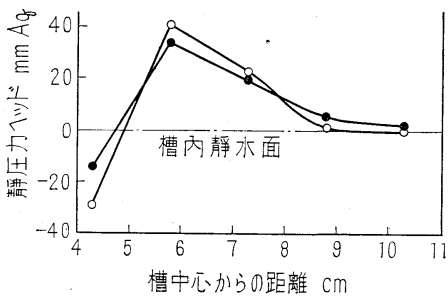

じやま板領域直 下の底面上に拈 ける静王力ヘッ ド及び円周速度 分布

$\left(H_{s} / D=0.05\right.$, $z=24, u=6 \mathrm{~m} / \mathrm{sec}$, $H_{0} / D=0.02$

ま板直下の領域内で糸流し行なつてみると,この領域 内の水は, インペラ直下にコアが存在する場合には, 全 体がコアと共回りしており，インペラ直下にコアが存在 しない場合には，8つの部分に分かれてほぼじやま板の

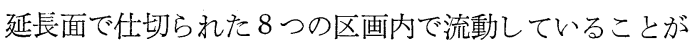
わかる。

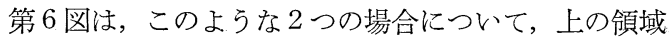
内に㧤いて底面からの高さ $H_{m}$ が約 $0.1 H_{s}$ 及び約 0.9 $H_{s}$ の位置に存在する 2 つの水平断面内で采流しを行つ て得られた, 各断面内における流れの方向, 向きおよび 上昇，水平，下降の各流れの分布状態を示す。これらの 図において，小丸は測定の位置を示し，小丸に連なる矢 印線は系の底面に対する投影の方向, 向きを示すと同時 にその長さを, 糸が水平な時を 1 として, 糸が水平面に 対して $45^{\circ}$ 以下の傾斜の時に $2 / 3,45^{\circ}$ 以上の傾斜の時に $1 / 3$, 垂直の時にゼ口と定めて, 糸の水平面に対する傾斜 度合を区別している。

ビやま板直下の領域内の水がコアと共回りする場合に は，第6図(a)(b)に示されるように，この領域に泣中 央に近い内側の輪形の部分に下降流が一様に流入してき て底面を打つた後, 槽の側面に沿いじやま板領域に向つ て上昇し，流動が整然としている。水が水平面内で旋回 する時に，中心に強制渦が存在すれば，その外方は強制 渦でない限り自由渦であるのが一般である 3 から，共回 り流れは当然自由渦の成分を含む流れであると想像され る。そこで共回り流れが自由渦成分を含むか否かを知る ために, 底面上における圧力と円周速度とを測定してみ ると，第 7 図に示される結果を得る。ただし第 7 図の円 周速度線図に示される破線群は, 自由渦注ける円周速

a) コアはその水平断面内で円周方向と半径方向とに分速度をもつ流れ であるので，この旋回成分が隇殺されてくると輻流がはつきり現わ れてくる。 
度分布曲線である。第 7 図をみれば, 静圧力へッド分布 曲線には大きい動圧の影響を含さ部分がみられるのでこ の曲線清静圧力へッド分布を与えないが，円周速度分布 曲線は全く医転点をもつていないので，大まかには円周 速度の概略的な傾向を表わすと考えることができる。こ のような円周速度分布曲線の形状によつて判断すれば共 回り旋回流は自由洞成分をもつことが明らかであり，し たがつて，じやま板付き槽の槽底における流孔は，イン ペラ直下にコアが存在する場合には，極的て大まかには 近似複合渦であるといえる。

第 7 図に示される円周速度は，槽中心からの距離吕増 すにしたがつて急に低下し小さい值となるが，これは円 周速度がじやま板によつて抑制され，その代りに第6図 加ら察知されるように上昇速度が強化される結果と考え

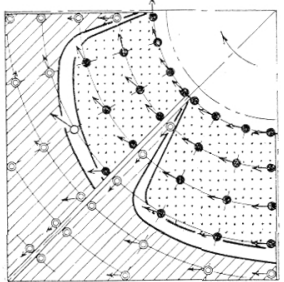

(a)

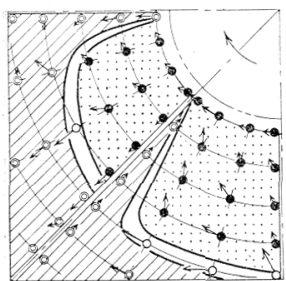

(b)

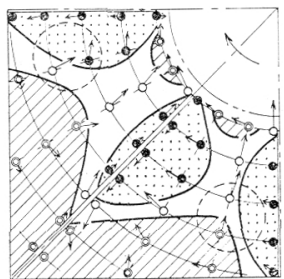

(C)

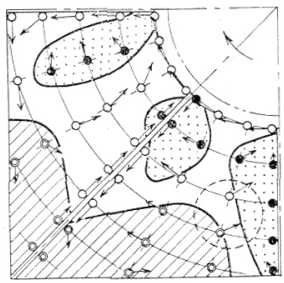

(d) (a), (b) अ $H_{0} / D=0.02$, (c), (d) अ $H_{0} / D=0.05$ の时 (a), (c) は $H_{m} \fallingdotseq 1.1 H_{s}$, (b), (d) \& $H_{m}=2 H_{s}$ の場会

第 8 圈しやま板領域内に拈ける流動 $\left(H_{\mathrm{s}} / D=0.05, z=24, u=6 \mathrm{~m} / \mathrm{sec}\right)$

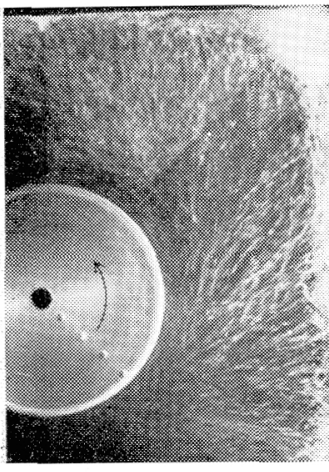

(a) $H_{0} / D=0.02$

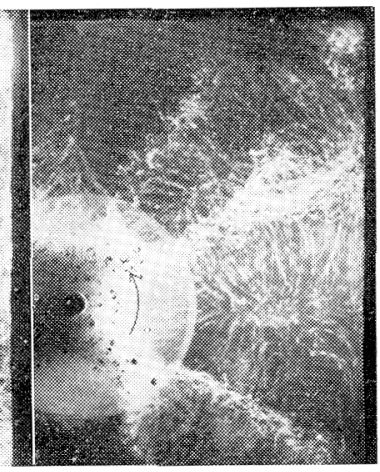

(b) $H_{0} / D=0.05$
第 9 図スリット光線光幕内に打引る珪砂の流れ模様 $\left(H_{s} / D=0.05, z=24, u=6 \mathrm{~m} / \mathrm{sec}\right)$
られる。なおこのような円周速度分布出線の形状は， 永田らがじやま板付き円筒形槽と低速かい型翼とを使用 して得た該槽内の円周速度分布曲線の形状》によく似て いるが，この類似はじやま板の特性に因るものと考えら れる。

じやま板直下の領域内の水吕，上述のをらな8つの区 画内で流動する場合には，第6四（c)，（d）に示される よらに，この領域内に流入する流れはじやま板領域から の下降流だけであり，この下降流は各しやま板直下の底 面孛打つた後，反対向きの二流に分岐して，それぞれじ や东板の延辱面で仕切られて隣合ら区画に侵入するので 各区画の底面上の中央辺には间合つて進んでくる二流の 衝知が起こり，この結果この区画内から一部の水がイン ペラ下部に向つて押出され，残部の水がじやま祯領域に 上昇するものと推察される。な扮第 6 四に示される破線 は，その中に珮流が存在守るとみられる区域の拉よ之 の輪郭圭示す日のでこの輪郭は実験の際に不安定な動 きを示した系の位置ならびに第6四と後揭の第8四とを 参照して推定した

\section{$3 \cdot 1 \cdot 3$ じやま板領域内における流動図}

第 8 図注 $H_{0} / D$ が 0.02 と 0.05 のつの場合につ

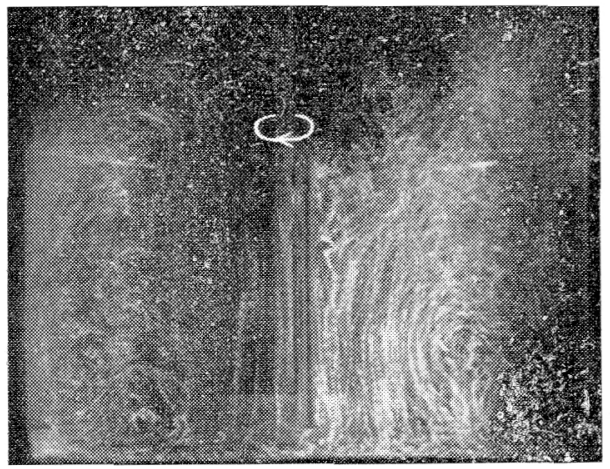

(a) $H_{0} / D=0.02$

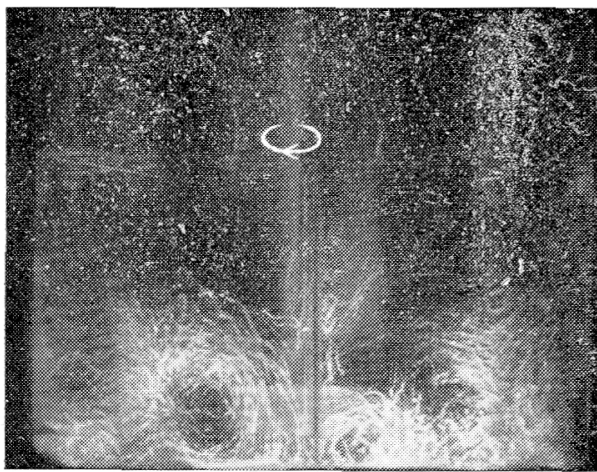

(b) $H_{0} / D=0.05$

（珄砂：粒度 $=20 \sim 32 \mathrm{mesh}$ ，比重 $=2.6$ ，投入率 $=0.4 \%$ 容皘）

第10図スリット光線光幕内に出ける珪砂の流れ模様 $\left(H_{s} / D=0.05, z=24, u=6 \mathrm{~m} / \mathrm{sec}\right)$ 
いて糸流しを行なつて得られた, じやま板領域内の比較 的下部にある 2 つの水平断面 $\left(H_{m}=1.1 H_{s}\right.$ 及び $H_{m}=$ $\left.2 H_{s}\right)$ 内における流動図である。これらの図における小 丸，矢印線及び破線区域つ意味ならびに上昇，水平，下 降の各流れの存在範团を示寸記号は第 6 図におけると同 ビである。第 8 図に示される結果により,インペラ直下 にコアが存在する場合の各じやま板区画内の流動には, 局部渦流や広範囲に亘る停滞部がなく, 一区画内におけ る上昇流と下降流が判然と二分されているので，各区画 内には上下方向に一つの強力な対流が生じて整然とした 循環路を形作つており，またインペラ直下にコアが存在 しない場合の各じやま板区画内の流動には，局部渦流が みられるのみならず水平流が広く分布しているので，各 区画内の上下方向に生ずる対流の強さと循環の具合は, インペラ直下にコアが存在する場合に較ベて劣るものと 考えられる。

\section{$3 \cdot 1 \cdot 4$ 固形粒子の流れ模様とインペラの限界設 置高} 度：じやま板付き槽内における固形粒子の動態は, じや ま板なし槽における時と同様に，主として $H_{0}$ によつて 変化し, かつこの変化は $H_{0}$ のある特定な值 $H_{e}$ におい てとくに著しいので，Heの上下では粒子の動態が全然 異なつた型を呈する。

第 9 図及び第10図は，それぞれスリット光線光幕を第 1 図に示じた水槽の水平断面 $x x$ 及び鉛直断面 $y y$ の 位置に作つた時に, $H_{0} \gtrless H_{e}$ の各埸合について, この光 幕内でみられる珪砂の流れ模様の写真である。第 9 図に 示される砂粒の流れ模様には, 第 3 図及び第 6 図に示し た水の流動々同じ傾向が認为られ，第10図に示される砂 粒の流れ模様には，第 8 図によつて推察したじやま板領 域内の対流の状態や第 6 図，第 8 図なごによつて推定し

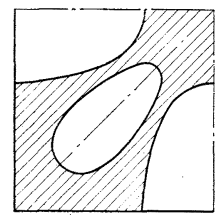

(1)

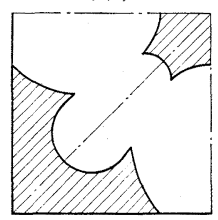

(2)

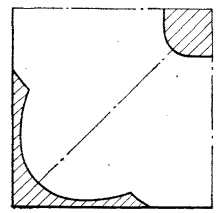

(3)

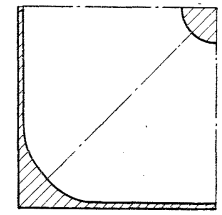

(4)

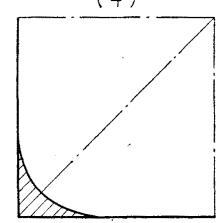

(5)

珪秒の浮上区域 珪砂吃沉皘区域 㥞
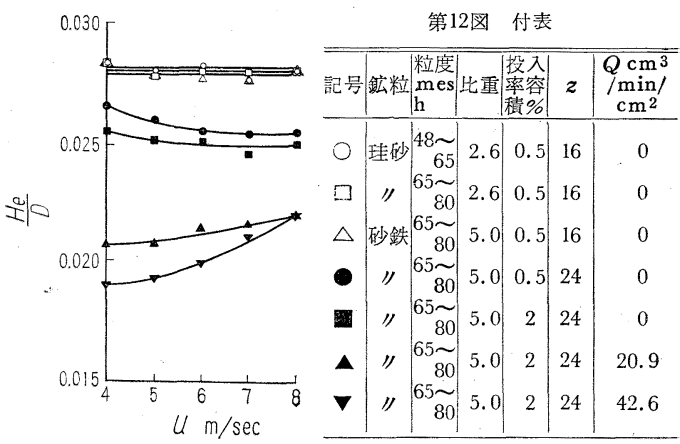

第12図 $H_{e} / D$ の值 $\left(H_{s} / D=0.05\right)$

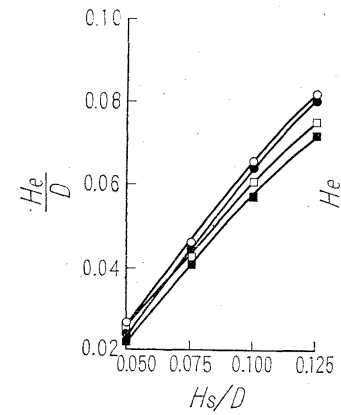

(a) $u=8 \mathrm{~m} / \mathrm{sec}$

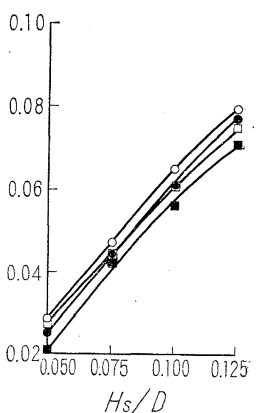

(b) $u=4 \mathrm{~m} / \mathrm{sec}$

$$
\begin{array}{ll} 
& z=16, Q=0 \\
\square & z=24, Q=0
\end{array} \quad \begin{aligned}
& z=16, Q=20.9 \mathrm{~cm}^{3} / \mathrm{min} / \mathrm{cm}^{2} \\
& z=24, Q=20.9 \mathrm{~cm}^{3} / \mathrm{min}_{i}^{\prime} \mathrm{cm}^{2}
\end{aligned}
$$

第13図 $H_{e} / D$ と $H_{s} / D$ との関係

た局部渦流の存在をほぼ裏付けるような部分が認められ る。

なお，第11図は鉱粒投入率b)がやや多い場合に底面上 に画かれる鉱粒の流れ模様のスケッチで, 流れ模様は $H_{0} / H_{s}$ の值が小さくなるにしたがつて番号の順序で変 化し, $H_{0}=H_{e}$ の時が(3)図に相当する。

以上に述べたことによつて, $H_{e}$ はじやま板付き槽内

\section{第11図}

槽底面上に拉け る珪砂の流れ模 様

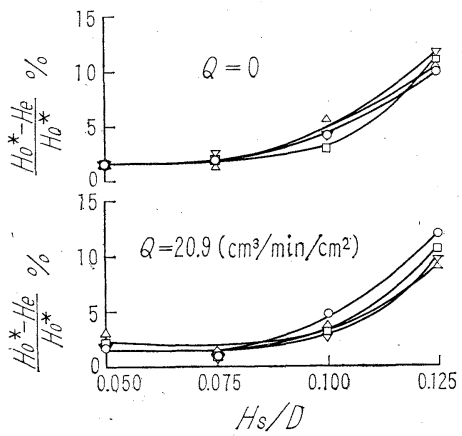

$\begin{array}{lll}\bigcirc=24, u=8 \mathrm{~m} / \mathrm{sec} & \triangle z=16, u=8 \mathrm{~m} / \mathrm{sec} \\ \square & z=24, u=4 \mathrm{~m} / \mathrm{sec} & \nabla z=16, u=4 \mathrm{~m} / \mathrm{sec}\end{array}$

第14図 $\left(H_{0} *-H_{e}\right) / H_{0} *$ の值 b) パルブ浱度のことである。かくはんだけを対象として実験してい るので，とくにこの語を用いた。 
における粒子の動態を支配するインペラの限界設置高度 であるといえるが，このような $H_{e}$ の值を珪砂と砂鉄を 使用した場合について測定し， $H_{e} / D$ の形で表示すると 第12罒に示される結果となる。この図に示される $H_{e}$ は 鉱粒投入率が増せば減少するが，鉱粒の比重，粒度によ つてほとんど不変である。 $H_{e}$ はまた $z, Q$ が増せば減 少し, $u$ が増せば, $Q=0$ の場合には, 減少またはほぼ 不変であり, $Q>0$ の場合には増加する。第13図は, 粒 度 65 80mesh，比重 5.0 の砂鉄を $0.5 \%$ 容積の割合で投 入した場合に, じやま板の各設置高度について $H_{e} / D$ を 求めた結果であるが，この図における $H_{e} / D$ は $H_{s} / D$ とともに増加している。

第13図と第 5 図の結果を比較すれぼ, $H_{e}$ と $H_{0}$ * の $H_{s} / D, z, u, Q$ に対して変わる傾向がほぼ一致している ので, $H_{e}$ は $H_{0}$ * に密接に関連していることがわかる。 この関連の度合を探るために, 第13図と第 5 図とによつ てじやま板の各設置高度における $H_{e}$ の $H_{0}{ }^{*}$ に対する 変化率を求めてみると, 第14図に示されるよらな結果を 得る。この結果によれば, $H_{e}$ は $H_{0}$ * に較べて常に減 少し, その減少率はほぼ $H_{s} / D$ とともに増している。 しかしその減少率が $H_{s}: D$ の大きなな範囲内で数\%程 度の僅少な值となつている点からみて, $H_{e}$ はこのよう な $H_{s} / D$ の範囲内では主として $H_{0}$ *によつて左右され る值と考えられる。な羊 $H_{e}$ の $H_{0}$ *に対する減少率が $H_{s} / D$ とともに増すのは, $H_{s} / D$ が増せば $H_{0}$ * が増す ので, このために底面流の速度が減少する結果と推察さ れる。

\section{$3 \cdot 2$ じやま板付き䄚の槽底におけるかくはん強さc)}

水槽の底面積及びかくはえ中に底面上に沈積する鉱粒 の底面上に占める面積をそれぞれ $A, a$ とすれば，(Aa)/A なる值はこのかくはんにおける鉱粒の底面上から の浮上率を表わすと同時に槽底における流れによつて底 面が受けたかくはん効率を表わす一 つの尺度とも考えられるので, この 值をもつて槽底におけるかくはん強 せの比較值と孝えてみた。

第15図は, 粒度 65 80mesh, 比 重 5.0 の砂鉄を $10 \%$ 重量の割合で水 槽に投入した時について求めたこの ような浮上率の值を示す。この実験 における $H_{e} / D$ の值は， $Q=0$ の 時に約0. 023 0. 025, $Q>0$ の時に 約 $0.020 \sim 0.022$ になるが，第15図

c)このかくはん強さは, 槽底に利ける流れ によつて底面が受けたかくはん効果のこ とで，前報においてかくはん半径をるっ て表わした時のかくはん強さと同様けな意 味をるつ。

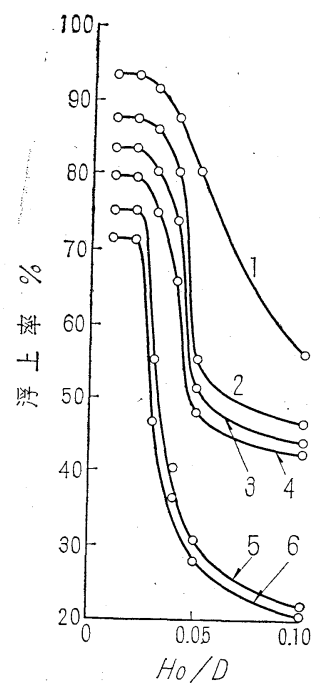

1. $z=24, u=8 \mathrm{~m} / \mathrm{sec}, Q=0$

2. $z=16, u=8 \mathrm{~m} / \mathrm{sec}, Q=0$

3. $z=24, u=8 \mathrm{~m} / \mathrm{sec}$, $Q=20.9 \mathrm{~cm}^{3} / \mathrm{min} / \mathrm{cm}^{2}$

4. $z=24, u=8 \mathrm{~m} / \mathrm{sec}$, $\mathbf{Q}=42.6 \mathrm{~cm}^{3} / \mathrm{min} / \mathrm{cm}^{2}$

5. $z=24, u=4 \mathrm{~m} / \mathrm{sec}, Q=0$

6. $z=16, u=4 \mathrm{~m} / \mathrm{sec}, Q=0$

第15図 砂鉄の浮上率 $\left(H_{s} / D=0.05\right)$

における浮上率は $H_{0} / D$ が $H_{e} / D$ のこような值より も大きくない区域内で最高值を示しているので，槽底に おけるかくはん強さは $H_{0} \leqq H_{e}$ の時にとくに強大であ るといえる。

第15図に示される浮上率は, $H_{0} \leqq H_{e}$ の区域内におい ては， $z, u$ とともに増し， $Q, H_{0} / D$ が増せば減少して おり，これらの傾向はじやま板なし槽について求めたか くはん半径の $z, u, Q, H_{0} / D$ に対して変わる傾向と一致 している。また同上区域内の浮上率曲線の形状をじやま 板なし槽について求めたかくはん半径を使用して算出し た仮想の浮上率曲線の形状（この図は省略する）と比較 してみれば，両者はよく似ている。これによつてじやま 板付き槽の槽底におけるかくはん強さが $H_{0} \leqq H_{e}$ の区 域内で $z, u, Q, H_{0} / D$ に対して変わる傾向は, じやま板 なし槽の槽底におけるかくはん強さが $z, u, Q, H_{0} / D$ に 対して変わる傾向と較べて, ほとんご同㥞と考えられる。

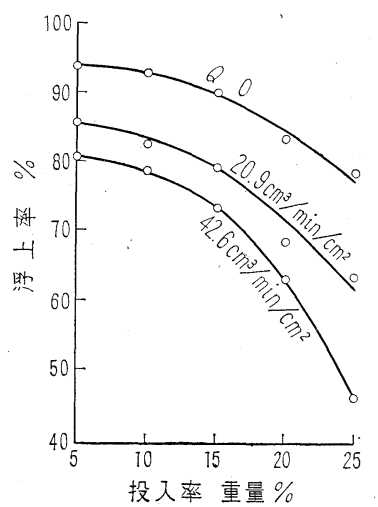

第16図 砂鉄の浮上率と投 入率との関係

$\left(H_{s} / D=0.05, z=24\right.$, $u=8 \mathrm{~m} / \mathrm{sec}, H_{0} / D=0.02$ )

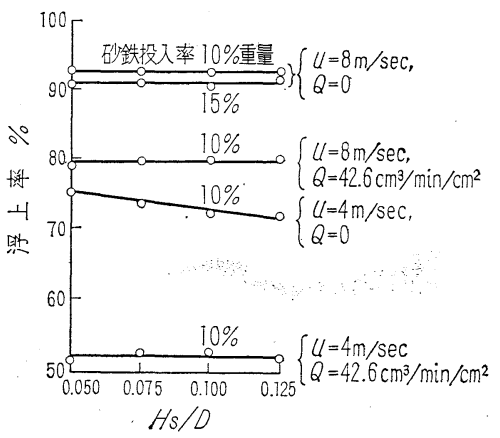

第17図 砂鉄の浮上率とじやま板設 置高度々の関係 $\left(z=24, H_{0} / D=0.02\right)$ 
かくはえ強さの大きさがじやま板の存在によつて受け る影響は，正確に求めることが困難であるが，仮りに第 15図に示される浮上率の值と上述の上うなかくはん半径 から算出した仮想浮上率の值とをそのまま比較すること ができるものとみなして， $H_{0} / D=0.025$ の時における 両者の值を比較してみれば, 前者は後者化較心゙て約 6 15\%減少している。この点からみれば，じやま板付き槽 の槽底に打けるかくはん強さの大きさは, $H_{0}<H_{e}$ の区 域内ではじやま板の影響を受けて，じやま板なし槽の槽 底に㧍けるかくはん強さの大きさより減少はするがその 減少率は概して大きくないものと推察される。

第16図と第17図は，上と同じ砂鉄を使用し， $H_{0} / D=$ 0.02 条件下で，それぞれ砂鉄投入率及びじやま板設置 高度を変化した場合における浮上率を示す。第16図に示 されるように，砂鉄の浮上率は投入率が増せば減少して おり，この結果にはじやま板なし槽においてかくはん半 径が砂鉄投入率に対して変わる傾向と同一な傾向が認め られる。また第17図に示されるように, 砂鉄の浮上率は ビやま板の設置高度によつてほとんど影響されないよう である。

\section{4. 結言}

本研究の結果を要約すれば，次のとおりである。

1）〔゙やま板付き槽においては, インペラの設置高度 $H_{0}$ がある特定な上限值 $H_{0}$ * に達しない場合には, イン ペラの直下にいわゆるコアが存在し，コアの外方の流れ は自由渦成分を含む共回り旋回流となり，各じやま板区 画内には上下方向に一つの整然とした対流を生ずるが， $H_{0}>H_{0} *$ の場合には，インペラ直下の流動は輻流とな り, この外方の流れはじやま板の延長面で仕切られた各 区画内に分岐して流動し, 各じやま板区画内に生ずる上 下方向の対流は $H_{0}<H_{0}$ * の場合ほどには強力でないと 推察される。

2）インペラには鉱粒の動態を支配する限界設置高度 $H_{e}$ が存在する。鉱粒の条件が与えられる時の $H_{e}$ は, じやま板設置高度 $H_{s}$ が槽底面の一辺の長さに対して過 大でない範囲内では, 主として $H_{0}$ * の值によつて左右 される值と考えられる。

本実験に㧍ける $H_{e}$ の值は, 岭粒と運転の条件に応し て $H_{s}$ の約 38〜66\% となつている。

3）槽底に扔けるかくはん強さを鉱粒の底面上からの
浮上率をもつて表示すれば，この比較值は， $H_{0} \leqq H_{e}$ の 場合には, インペラのスリット数・周速上ともに増し, 外気量・インペラ設置高度及び鉱粒投入率が増せば減少 し，じやま板設置高度に対してはほぼ不変である。この 傾向はじやま板なし槽におけるかくはん半径がじやま板 設置高度を除く上のような諸元に対して変る傾向とほぼ 一致する。

4）かくはん強さの大きさは，じやま板の存在によつ て滅少するが，この減少率は $H_{0}<H_{e}$ の場合には十数 \%以下の比較的僅少なものと推察される。

5）槽底におけるかくはんが有効に行われるためには インペラの設置高度を限界值 $H_{e}$ より低く設定すること がまず第一に必要な条件である。

本研究について有益な数々の御助言を唇くした本学林 大輔教授に厚く御礼申上げるとともに，卒論として本実 験の遂行に努力した 37 年度卒業予定学生川越功・松井宏 の両君に深謝する。

\section{本論文に使用の記号}

$z:$ インペラのスリット数

$u:$ インペラの外周速度

$[\mathrm{m} / \mathrm{sec}]$

$Q:$ 供給空気量 $\left[\mathrm{cm}^{3} / \mathrm{min} / \mathrm{cm}^{2}\right]$

$D:$ 水槽の水平断面(正方形)内に㧍ける 一辺の長さ [mm]

$A:$ 同上槽の底面積 $\left[\mathrm{mm}^{2}\right]$

$a:$ かくはん中に槽底に沈積する鉱粒の 底面上に占好面積

$H_{0}:$ インペラの設置高度 $\left[\mathrm{mm}^{2}\right]$

$H_{0}^{*}$ : コアが存在する範囲内における $H_{0}$ の上限值 $[\mathrm{mm}]$

$H_{s}:$ じやま板の設置高度

$H_{m}$ : 水槽の水平断面内の流動図を求 める際に使用した底面からその 水平断面までの高さ

$H_{e}:$ 鉱粒の動態を支配するインペラ の限界設置高度

\section{文献}

1）著者：日本鈗業会誌，78巻，888号，昭和 37 年 6 月，460 466 頁

2）林大輔・中村虎重・山口忠蜼：日本釷業会誌，75巻，848号，昭和 32 年 2 月, $86 \sim 92$ 頁

3) 宮城音王郎：水力学 (昭和28年) 88 93頁

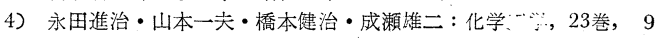
号，昭和 34 年，598頁 